\title{
WestVirginiaUniversity
}

THE RESEARCH REPOSITORY @ WVU

Graduate Theses, Dissertations, and Problem Reports

2021

\section{Biological Conversion of Carbon Dioxide to Value-added Chemicals}

Owen James McGrath

omcgrath@mix.wvu.edu

Follow this and additional works at: https://researchrepository.wvu.edu/etd

Part of the Biochemical and Biomolecular Engineering Commons, and the Catalysis and Reaction Engineering Commons

\section{Recommended Citation}

McGrath, Owen James, "Biological Conversion of Carbon Dioxide to Value-added Chemicals" (2021). Graduate Theses, Dissertations, and Problem Reports. 8293.

https://researchrepository.wvu.edu/etd/8293

This Problem/Project Report is protected by copyright and/or related rights. It has been brought to you by the The Research Repository @WVU with permission from the rights-holder(s). You are free to use this Problem/Project Report in any way that is permitted by the copyright and related rights legislation that applies to your use. For other uses you must obtain permission from the rights-holder(s) directly, unless additional rights are indicated by a Creative Commons license in the record and/ or on the work itself. This Problem/Project Report has been accepted for inclusion in WVU Graduate Theses, Dissertations, and Problem Reports collection by an authorized administrator of The Research Repository @ WVU. For more information, please contact researchrepository@mail.wvu.edu. 
Graduate Theses, Dissertations, and Problem Reports

2021

Biological Conversion of Carbon Dioxide to Value-added Chemicals

Owen James McGrath

Follow this and additional works at: https://researchrepository.wvu.edu/etd

Part of the Biochemical and Biomolecular Engineering Commons, and the Catalysis and Reaction Engineering Commons 
Biological Conversion of Carbon Dioxide to Value-added Chemicals

Owen J. McGrath

Problem Report submitted to the Statler College of Engineering and Mineral Resources

at West Virginia University

in partial fulfillment of the requirements for the degree of

Master of Science in Chemical Engineering

Jianli Hu, Ph.D., Chair

Charter D. Stinespring, Ph.D.

Jeremy S. Hardinger, Ph.D.

Department of Chemical and Biomedical Engineering

Morgantown, West Virginia

2021

Keywords: Carbon Dioxide, Enzyme

Copyright 2021 Owen J. McGrath 


\section{Abstract \\ Biological Conversion of Carbon Dioxide to Value-added Chemicals \\ Owen J. McGrath}

As Carbon Dioxide $\left(\mathrm{CO}_{2}\right)$ levels in the atmosphere continue to rise due to human intervention, there is increased urgency to take actions to mitigate the potential ramifications. Many countries have instituted a $\mathrm{CO}_{2}$ tax and have provided funding to finding potential solutions to our growing $\mathrm{CO}_{2}$ problem. Further investigating $\mathrm{CO}_{2}$ capture, sequestration, and utilization is key to combating rising $\mathrm{CO}_{2}$ levels and methods being investigated have increased substantially in recent years. Converting $\mathrm{CO}_{2}$ into fuels and value-added chemicals provides a unique opportunity to create materials of value from a substance that is being subsidized to use as a feedstock, as well as taking steps towards being a "net-zero carbon emission" culture. Energy efficient conversion of $\mathrm{CO}_{2}$ is crucial to achieve both environmental and economic benefits. Current methods being researched use enzymes to imitate the $\mathrm{CO}_{2}$ metabolic process found in many organisms. This review will elucidate the current methods for using enzymes for capture, sequestration, and utilization of $\mathrm{CO}_{2}$, as well as the expected future capabilities based upon ongoing research. 


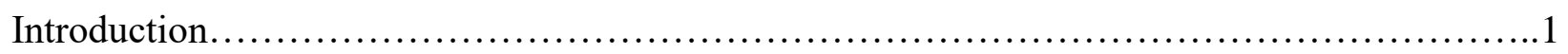

Carbon Dioxide Capture/Sequestration................................................. 4

Carbon Dioxide Utilization in Natural Processes.........................................4

Value Added Products from Carbon Dioxide............................................. 7

Enzymatic Conversion of Carbon Dioxide...................................................

Single Enzyme Processes................................................. 9

Enzyme Network Processes............................................. 12

Electro/Photo enzymatic Processes...........................................13

Enzyme Immobilization....................................................

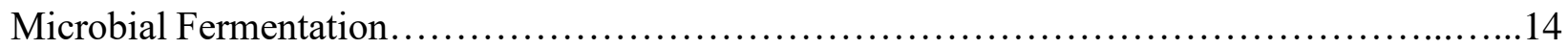

Discussion.................................................................... 16

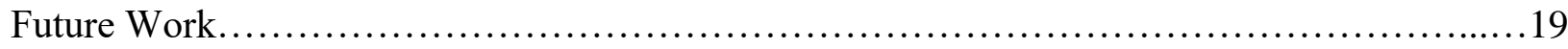

Conclusion................................................................... 19

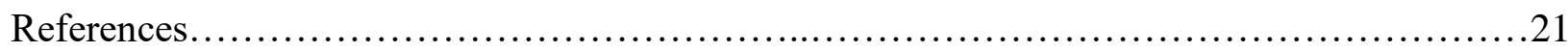




\section{Introduction}

Carbon Dioxide $\left(\mathrm{CO}_{2}\right)$ is of critical importance to all life on earth; atmospheric $\mathrm{CO}_{2}$ is the main source of carbon for biological processes. Plants and algae fix $\mathrm{CO}_{2}$ into carbohydrates via photosynthesis, and aerobic organisms produce $\mathrm{CO}_{2}$ during metabolic processes.

The rise in atmospheric $\mathrm{CO}_{2}$ due to human intervention has been widely recognized as a growing problem, with potential ramifications for life on Earth. The rise of atmospheric $\mathrm{CO}_{2}$ can be primarily attributed to the production of $\mathrm{CO}_{2}$ from combustion of fossil fuels. The principal reason the rise of $\mathrm{CO}_{2}$ in the atmosphere is concerning is due to $\mathrm{CO}_{2}$ 's behavior as a greenhouse gas. A greenhouse gas is defined as any gas that absorbs and emits infrared radiation [1]. Infrared radiation is electromagnetic radiation with a wavelength longer than visible light and is emitted or absorbed by molecules as they change their rotational and vibrational movement [2]. Sunlight provides about one kilowatt per square meter of energy at sea level. Of this energy, 500 watts are infrared radiation (450 watts of visible light and 50 watts of ultraviolet radiation make up the balance) [2]. Greenhouse gases absorb this infrared radiation, this in turn results in more energy being put into the atmosphere and causes an overall rise in average temperatures. This increase in energy absorption versus reflection changes the principal energy balance of the Earth.

$\mathrm{CO}_{2}$ emissions have been increasing since around the time of the industrial revolution (1750) and levels are approximately $45 \%$ higher now (415 ppm) than $\mathrm{CO}_{2}$ levels were then (280ppm) [3]. Historic $\mathrm{CO}_{2}$ concentrations are shown in Figure 1 and growth rate of $\mathrm{CO}_{2}$ emissions is shown in Figure 2. To combat the rise of atmospheric $\mathrm{CO}_{2}$, this problem is being approached from multiple angles. To reduce the amount of $\mathrm{CO}_{2}$ produced, reliance on fossil fuels is being reduced by utilizing more "green" energy (wind, solar, nuclear, etc.). Also, more 
"renewable carbon" fuels (biofuels) are being researched and put into operation. $\mathrm{CO}_{2}$ capture and sequestration are also being utilized to reduce emissions from burning fossil fuels. To reduce the amount of $\mathrm{CO}_{2}$ already present in the atmosphere, direct air capture (the process of capturing $\mathrm{CO}_{2}$ directly from the ambient air) and sequestration can be performed.

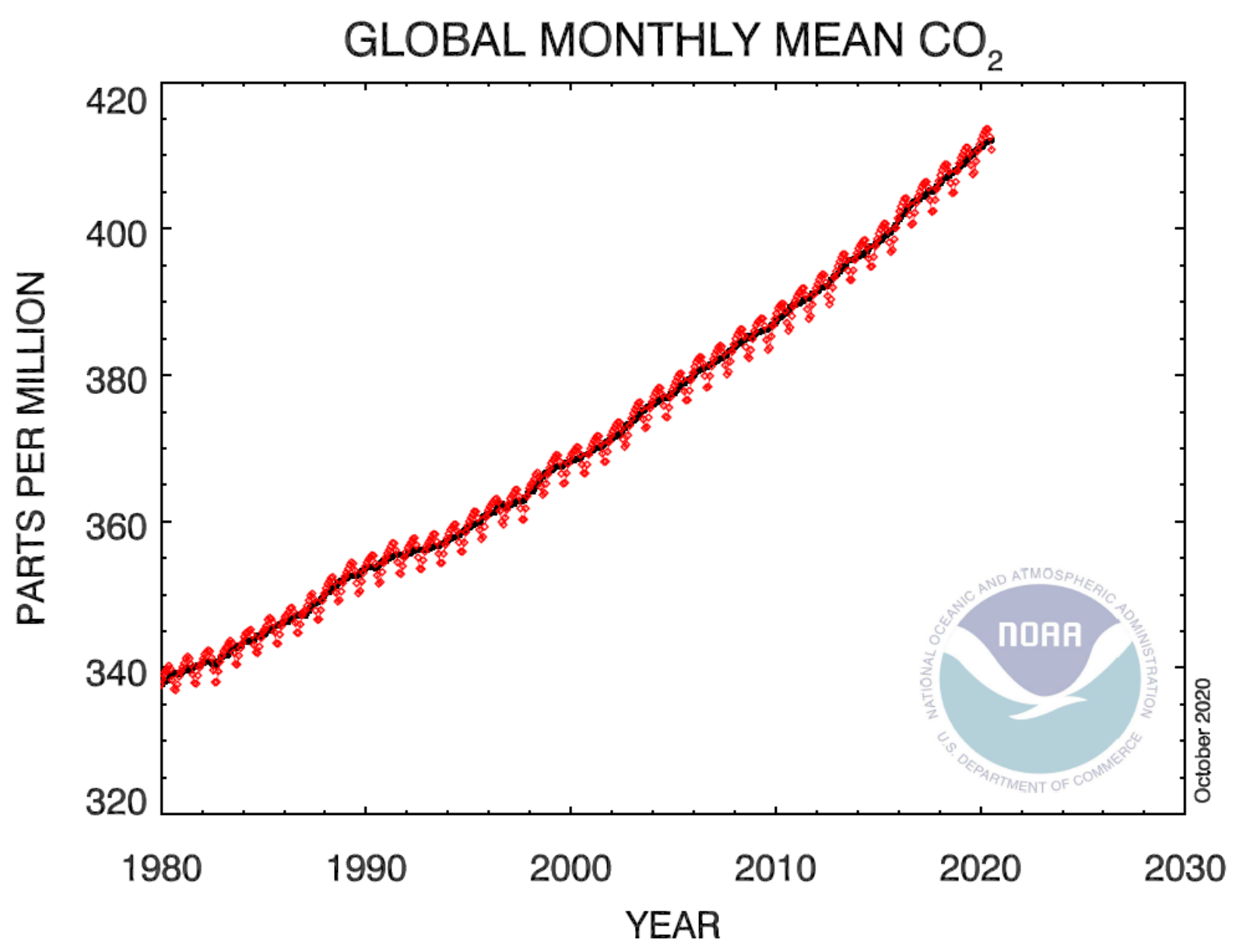

Figure 1: $\mathrm{CO}_{2}$ atmospheric concentration over the past 40 years. The red points are the monthly averages, and the yearly averages are denoted by the black line. [3] 


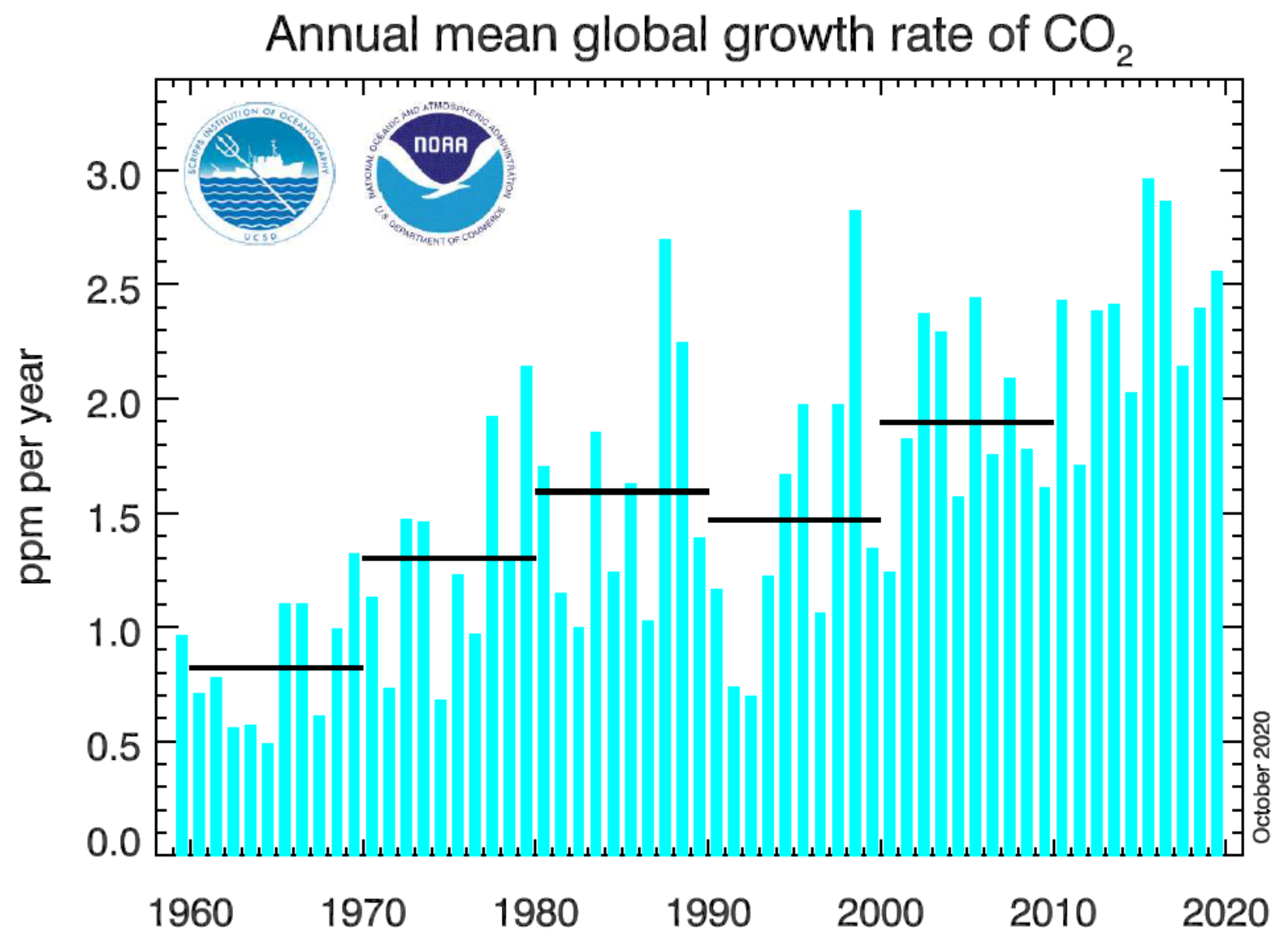

Figure 2: Growth rate of $\mathrm{CO}_{2}$ emissions over the past 60 years. The black bars signify the average increase in $\mathrm{CO}_{2}$ emissions for that decade. [3]

Utilizing $\mathrm{CO}_{2}$ for chemical production has been practiced since the 1880 's, namely in the production of urea [4]. Interest in using $\mathrm{CO}_{2}$ in chemical synthesis waned during the 1900's, with carbon monoxide $(\mathrm{CO})$ being the predominant method to supply carbon in the production of various chemicals and fuels.

One method for combating the rise of atmospheric $\mathrm{CO}_{2}$ is implementing a "carbon tax". This tax attempts to reduce emissions by placing a larger financial burden on entities that produce $\mathrm{CO}_{2}$. 


\section{Carbon Dioxide Capture/Sequestration}

$\mathrm{CO}_{2}$ capture and sequestration are the most effective method we currently have for reducing $\mathrm{CO}_{2}$ in the atmosphere. $\mathrm{CO}_{2}$ capture is the process of capturing $\mathrm{CO}_{2}$ produced from specific sources (such as the combustion of fossil fuels) by dissolution in a solvent such as monoethanolamine (MEA). This $\mathrm{CO}_{2}$, once captured, is then stored in tanks for later use or sequestration; an example scrubbing process is shown in figure 3.

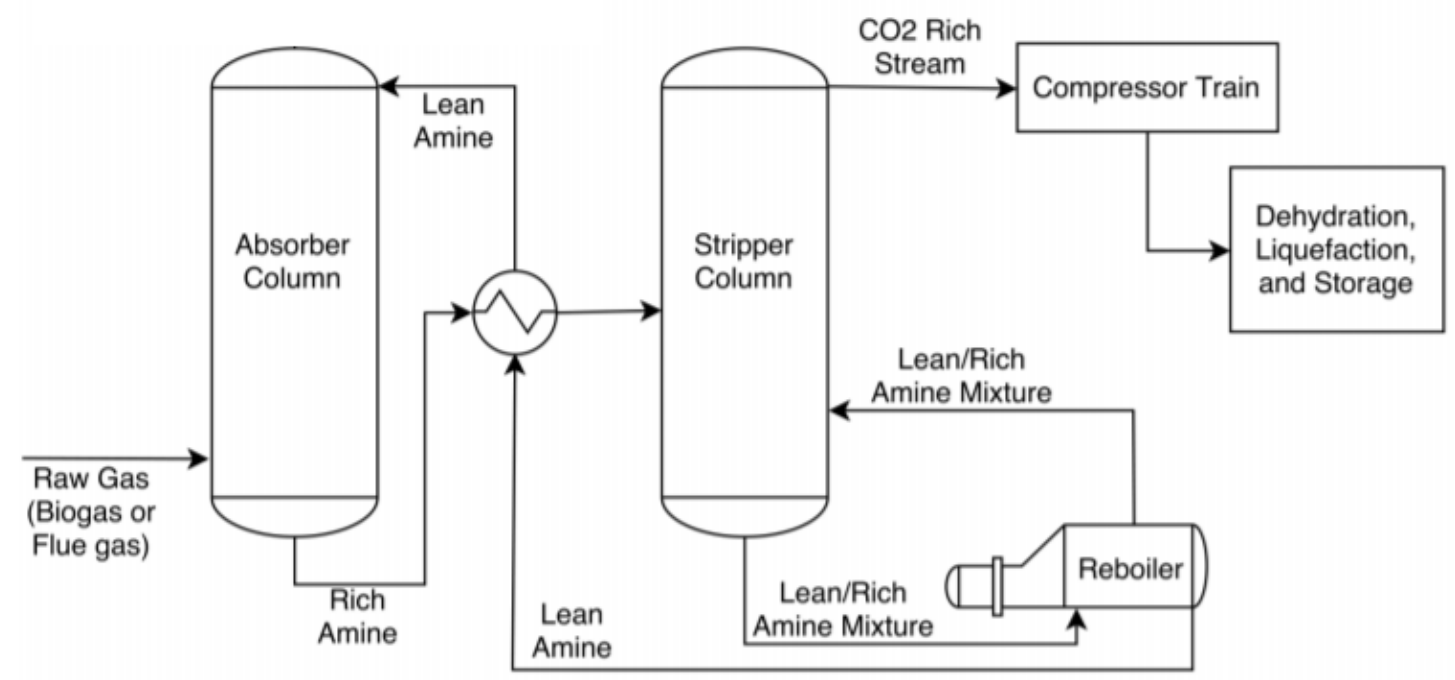

Figure 3: Process flow diagram of an example amine scrubber system [5]

\section{Carbon Dioxide Utilization in natural processes}

Carbon Dioxide plays a key role in some of the most basic forms of energy conversion in biological systems. There are six distinct cycles, with biological systems using one or more of these cycles to maintain homeostasis. These six cycles are shown in Figure 4. Of these six cycles, the most common is the Calvin cycle and is used by nearly all photosynthetic life. The 
Calvin cycle has three distinct mechanisms for $\mathrm{CO}_{2}$ utilization; $\mathrm{CO}_{2}$ fixation, $\mathrm{CO}_{2}$ reduction, and regeneration of the $\mathrm{CO}_{2}$ receptor, which allows the cycle to repeat. 


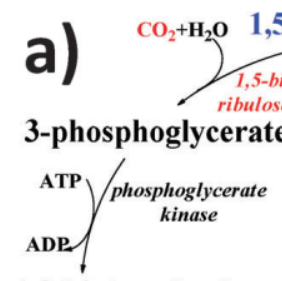

1,3-biphosphoglycerate

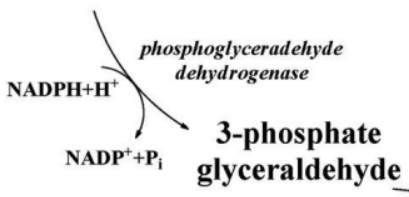

3-phosphate glyceraldehyde

sugar, fatty acids, amino acids

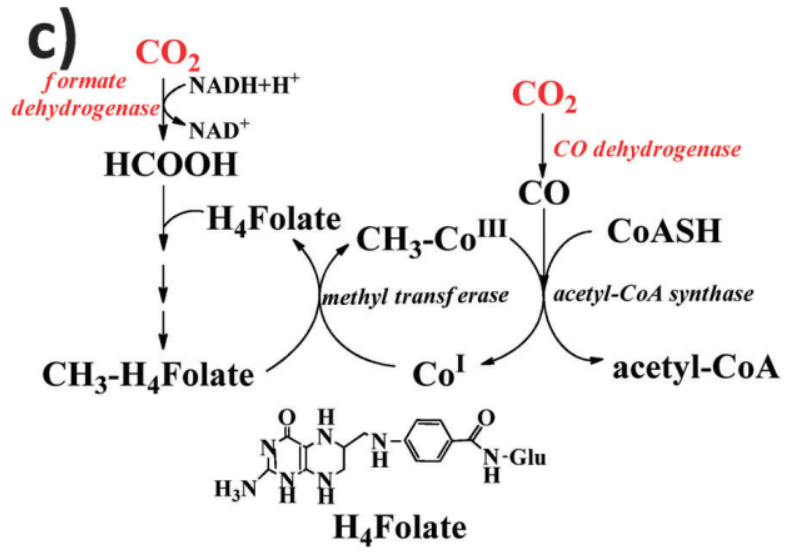

e)
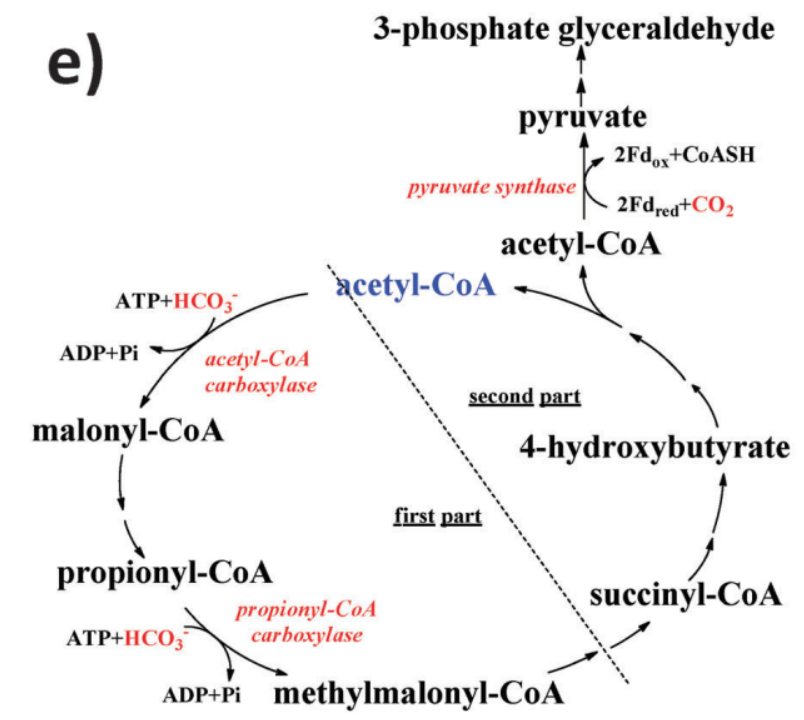
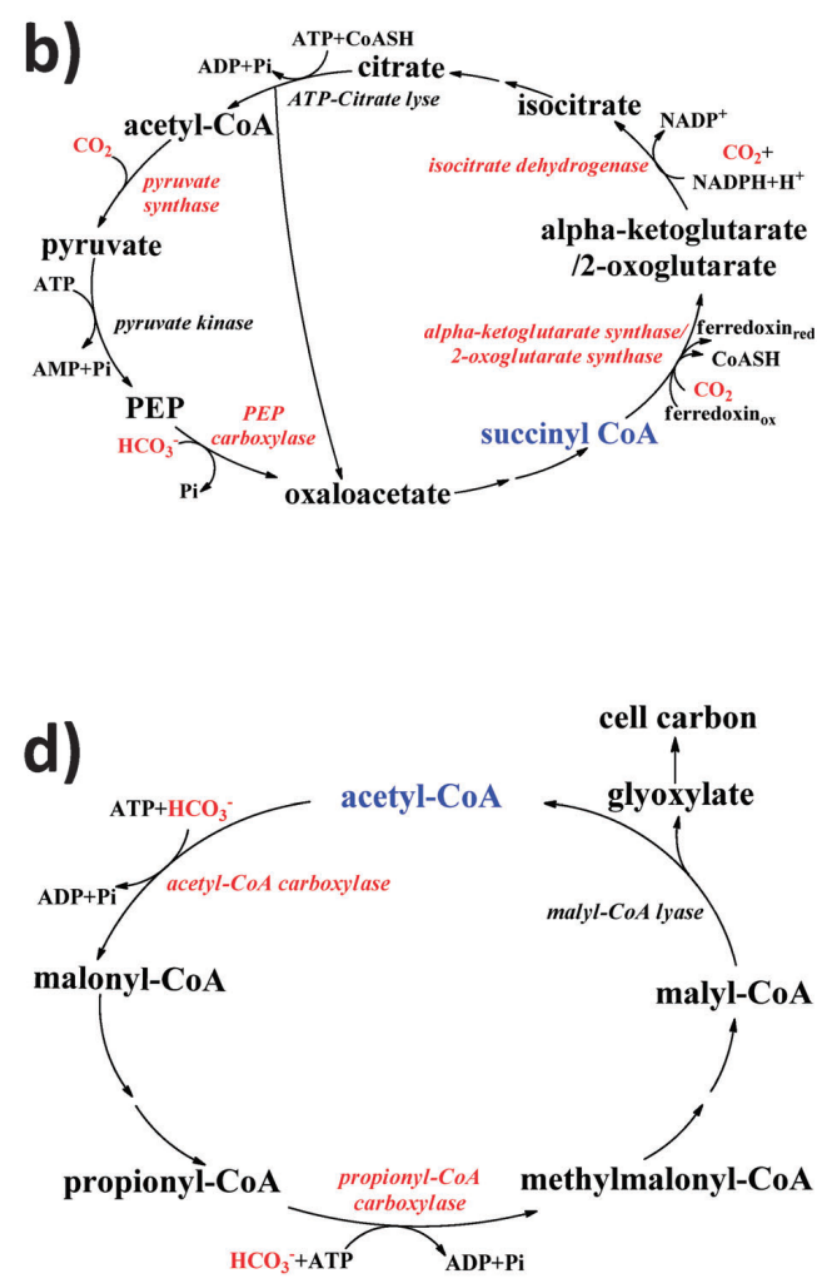

f)

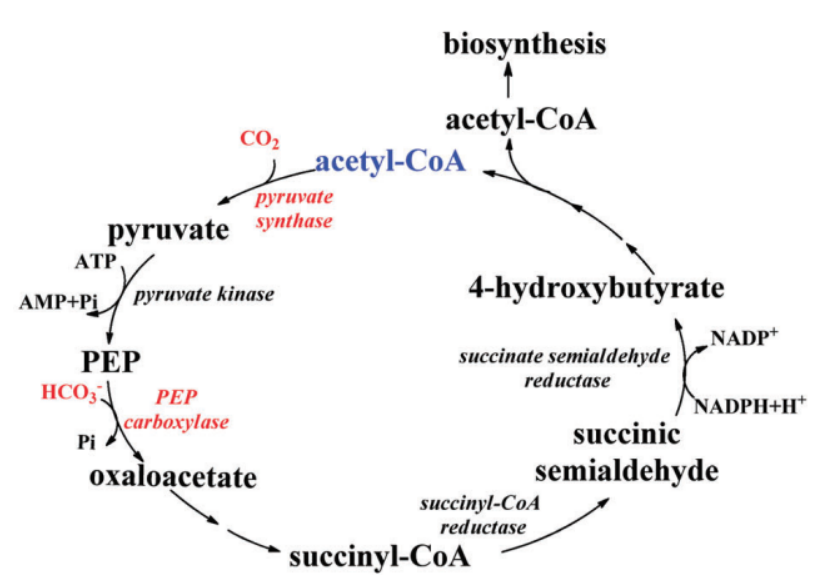


Figure 4: Six of the natural CO2 metabolic cycles: (a) Calvin cycle, (b) Reductive citric acid cycle, (c) Reductive acetyl-CoA route, (d) 3-Hydroxpropionate cycle, (e) 3Hydroxpropionate/4-hydroxybutyrate cycle, (f) Dicarboxylate/4-hydroxybutyrate cycle [6]

\section{Value Added Products from Carbon Dioxide}

\section{Fuels}

Investigating methods of deriving fuels from sources other than "fossil carbon" sources is a major field of study. Some of the most common fuels being investigated for production from $\mathrm{CO}_{2}$ are methanol and ethanol.

$\mathrm{CO}_{2}$ is a relatively low energy molecule, therefore, to build energy carrying molecules, such as fuels, energy must be added in some way. The difference in energy carrying capacity between $\mathrm{CO}_{2}$ and carbon-based fuels is easily seen when comparing the Gibbs free energies of formation. The Gibbs free energy of formation for $\mathrm{CO}_{2}$ and various relevant compounds is shown in Table 1.

\begin{tabular}{|c|c|c|}
\hline Compound & Chemical Formula & $\boldsymbol{\Delta G}_{\boldsymbol{f}}^{\circ}(\mathbf{k j} / \mathbf{m o l})$ \\
\hline Carbon Dioxide & $\mathrm{CO}_{2}$ & -394.39 \\
\hline Carbon Monoxide & $\mathrm{CO}$ & -137.16 \\
\hline Ethanol & $\mathrm{C}_{2} \mathrm{H}_{5} \mathrm{OH}$ & -174.8 \\
\hline Methanol & $\mathrm{CH}_{3} \mathrm{OH}$ & -166.6 \\
\hline
\end{tabular}

Table 1: Gibbs free energy of formation of relevant compounds (at $25^{\circ} \mathrm{C}$ and $1 \mathrm{~atm}$ )[17] 
The problem with converting $\mathrm{CO}_{2}$ to various fuels is twofold: first, where does the additional energy come from, and second, where does the hydrogen that are in the composition of these fuels come from? The answers to these questions are different for organic and inorganic production methods.

For inorganic methods of producing $\mathrm{CO}_{2}$, the energy source is typically in the form of heat. This heat can be supplied through various means, however if the aim is to reduce net carbon in the atmosphere, renewable energy sources such as wind, solar, and geothermal should be utilized. The typical source of hydrogen is diatomic hydrogen itself, with that hydrogen typically being supplied through methods such as steam methane reforming and water gas shift reaction.

For organic conversion methods, the energy source can come from a variety of methods, including ultraviolet radiation, electrical potential, or energy carrying molecules (ATP, GTP, and $\mathrm{NADH}$ ) and may require a specific combination of those sources. The typical source of hydrogen is through an energy carrying molecule.

Feedstock chemicals that can be synthesized from $\mathrm{CO}_{2}$ include carbon monoxide $(\mathrm{CO})$, formate, bicarbonate, urea, and various carboxylic acids.

\section{Enzymatic Conversion of Carbon Dioxide}

Single enzyme processes for conversion of $\mathrm{CO}_{2}$ to useful products are less common than enzyme network processes. In addition to typically requiring a complex system of enzymes working in tandem, these processes also require energy to be added, usually in the form of adenosine triphosphate (ATP), guanosine triphosphate (GTP), nicotinamide adenine 
dinucleotide (NAD or NADH for the reduced form), or nicotinamide adenine dinucleotide phosphate (NADP or NADPH for the reduced form). $\mathrm{CO}_{2}$ has a very low Gibbs free energy, requiring energy from an external source to facilitate reacting $\mathrm{CO}_{2}$ into various products.

\section{Single Enzyme Processes}

Single enzyme processes for synthesis of products from $\mathrm{CO}_{2}$ generally fall into one of two categories; oxidoreductases and lyases (synthases can also be used; however, their products are often not useful outside of the cellular setting).

Oxidoreductases are enzymes that assist in the transfer of electrons (oxidation-reduction, or redox reaction) between two molecules (a reductant to oxidant). The typical electron donors for these reactions are NAD and NADP. Oxidoreductases are found naturally in chloroplasts and mitochondria.

One of the products of oxidoreductases that has the most uses is formate. Formate has multiple industrial applications, including methanol and hydrogen production, fuel cells, and used in dyes. The reaction for conversion of $\mathrm{CO}_{2}$ into formate is given in Equation (1).

$$
\mathrm{CO}_{2}+\mathrm{H}^{+}+2 e^{-} \rightarrow \mathrm{HCOO}^{-}
$$

The enzyme used for conversion of $\mathrm{CO}_{2}$ to formate is Formate Dehydrogenase $\left(\mathrm{F}_{\mathrm{ate}} \mathrm{DH}\right)$ and utilizes NADH as a cofactor. The mechanisms for this reaction are shown in Figure 5. One of the issues with this process is the consumption of NADH; continually adding new NADH quickly forces this process to become financially unreasonable. To circumvent this problem, it is 
necessary to regenerate the NADH used as the cofactor; the method commonly utilized is an artificial photosynthetic system that will be further discussed in the photo-enzymatic process section.
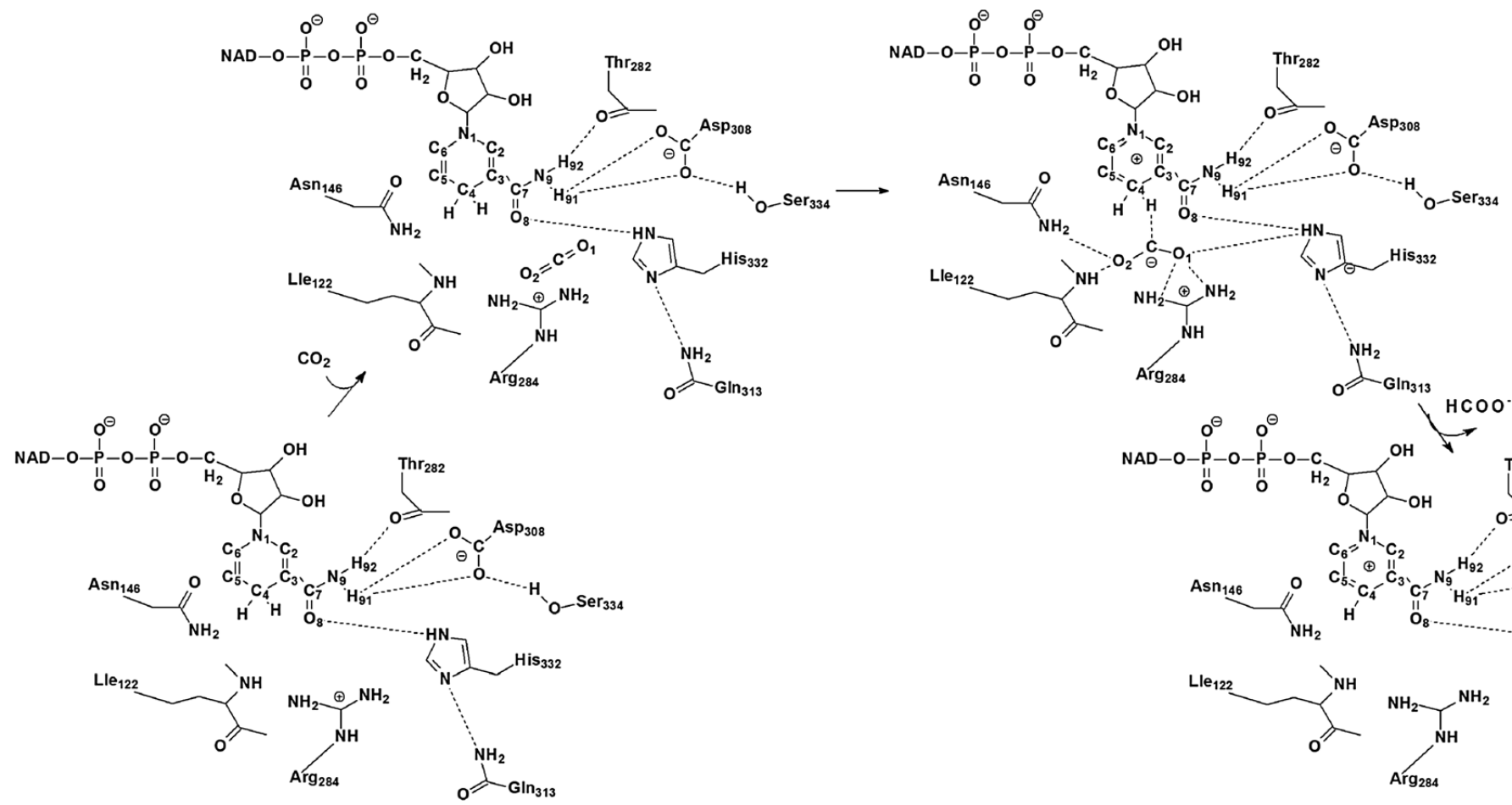

Figure 5: Reduction of $\mathrm{CO}_{2}$ to formate by $\mathrm{F}_{\text {ate }} \mathrm{DH}$ with cofactor of NADH [7]

The next product of oxidoreductases with multiple uses is $\mathrm{CO}$. $\mathrm{CO}$ is used in processes ranging from methanol production, acetic acid production, as well as the Fischer-Tropsch process. The reaction for conversion of $\mathrm{CO}_{2}$ into $\mathrm{CO}$ is given in Equation (2).

$$
\mathrm{CO}_{2}+2 \mathrm{H}^{+}+2 e^{-} \rightarrow \mathrm{CO}+\mathrm{H}_{2} \mathrm{O}
$$

The enzyme used for conversion of $\mathrm{CO}_{2}$ to $\mathrm{CO}$ is $[\mathrm{NiFe}] \mathrm{CO}$ Dehydrogenase ([NiFe] CODH). The mechanism for reduction of $\mathrm{CO}_{2}$ to $\mathrm{CO}$ by [NiFe] $\mathrm{CODH}$ is shown in Figure 6 . 


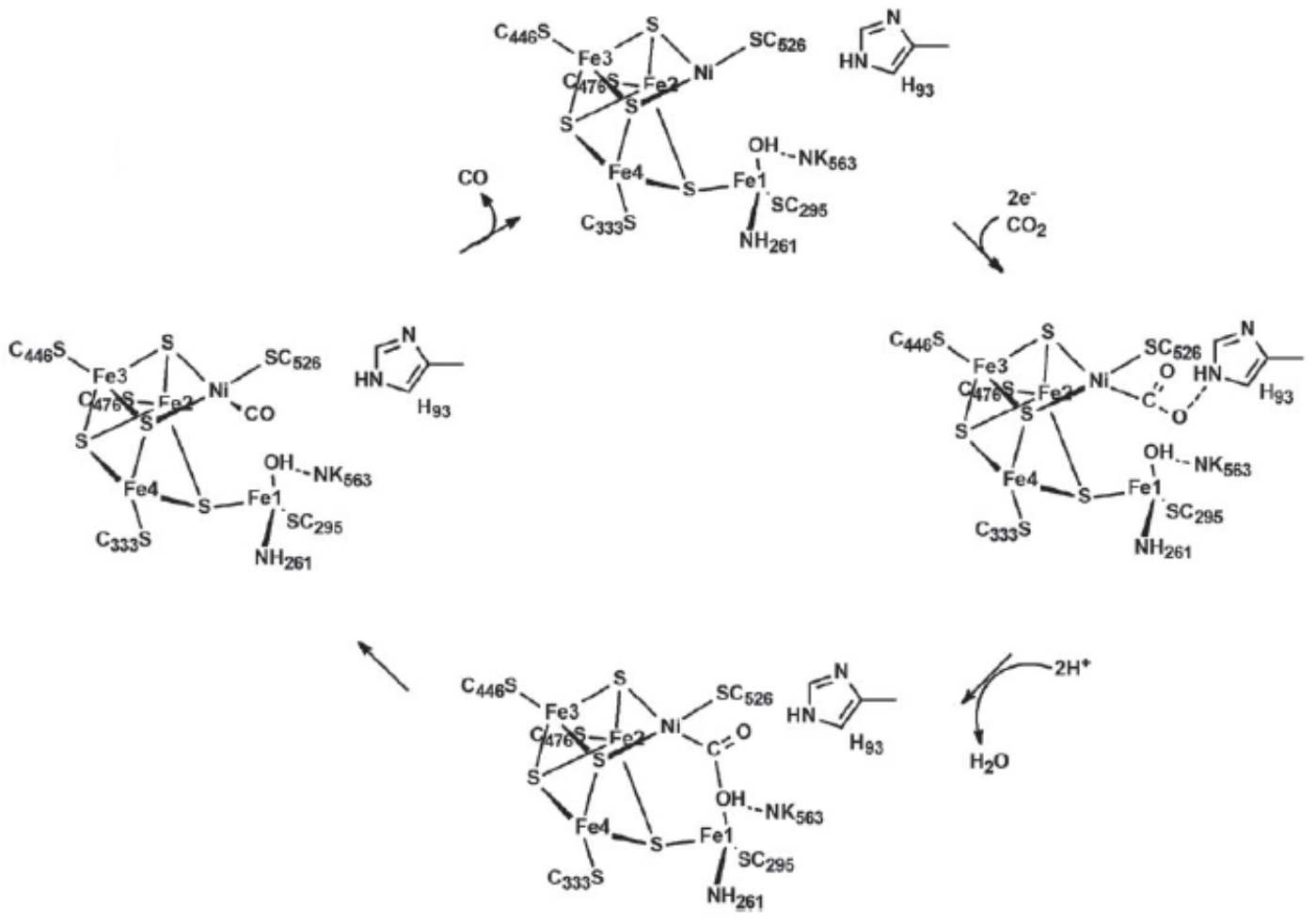

Figure 6: Reduction of $\mathrm{CO} 2$ to $\mathrm{CO}$ by [NiFe] $\mathrm{CODH}[8]$

Lyases are enzymes that assist in the breaking of chemical bonds by means other than hydrolysis or oxidation. The products of lyase catalyzed reactions typically have double bonds or ring structures.

One lyase product that is common in nature is bicarbonate $\left(\mathrm{HCO}_{3}^{-}\right)$. Bicarbonate is used on organisms to regulate $\mathrm{pH}$, particularly in the blood stream and in the digestive tract. The reaction for conversion of $\mathrm{CO} 2$ into bicarbonate is given in Equation (3).

$$
\mathrm{CO}_{2}+\mathrm{H}_{2} \mathrm{O} \rightarrow \mathrm{H}^{+}+\mathrm{HCO}_{3}^{-}
$$

The enzyme used for conversion of $\mathrm{CO}_{2}$ to bicarbonate is Carbonic Anhydrase (CA). The mechanism for hydration of $\mathrm{CO}_{2}$ to $\mathrm{HCO}_{3}{ }^{-}$by $[\mathrm{Zn}] \mathrm{CA}$ is shown in Figure 7 . 


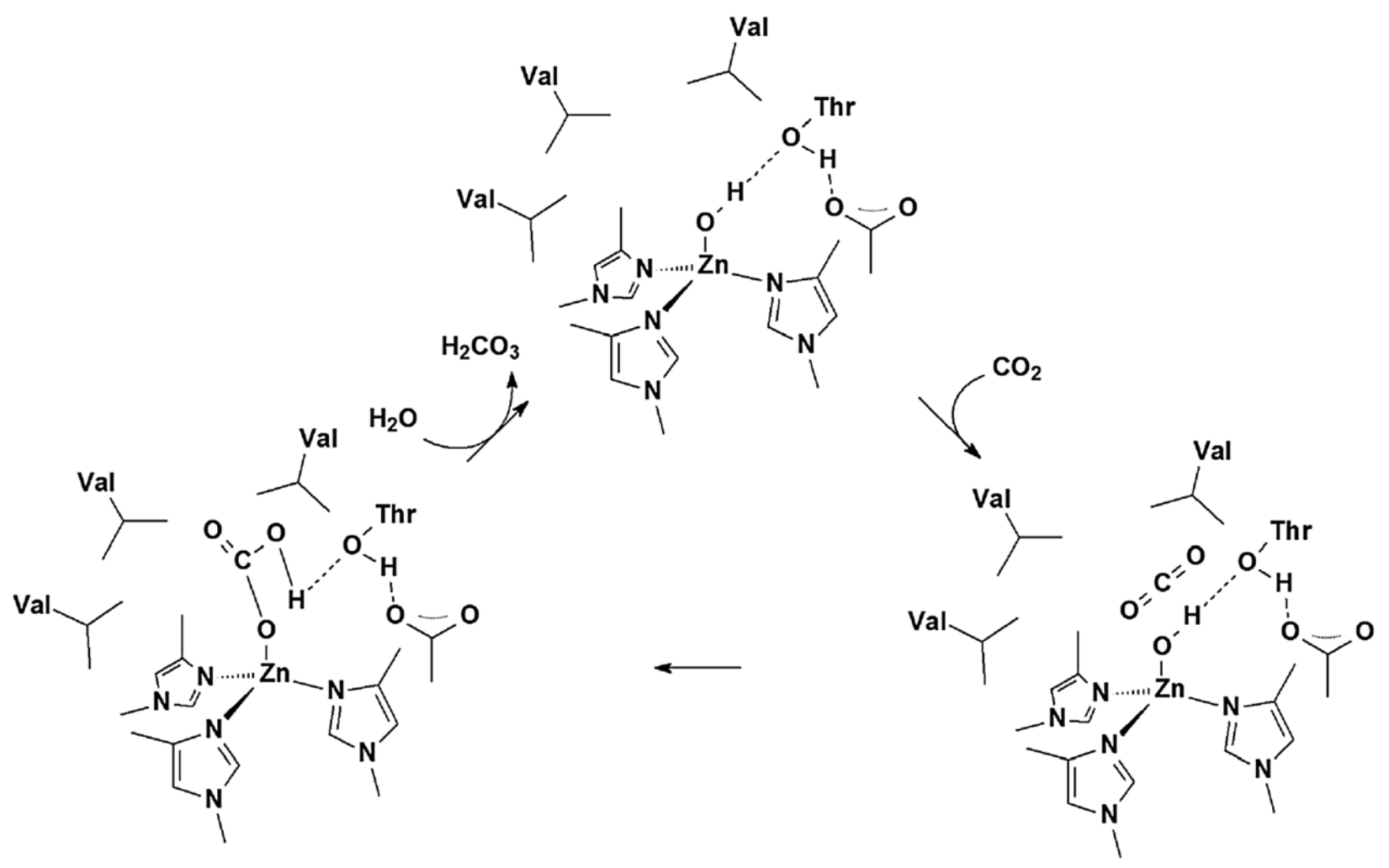

Figure 7: Hydration of $\mathrm{CO} 2$ to $\mathrm{HCO}_{3}^{-}$by [Zn]CA [8]

\section{Enzyme Networks}

Enzyme networks are much more common in natural processes and tend to be more effective than single enzyme processes, with more varied possible products; nearly all naturally occurring $\mathrm{CO}_{2}$ utilization processes are enzyme networks. While enzyme networks have the benefit of being more flexible in desired product, they are more difficult to manage in an in vitro setting.

One of the most promising products of $\mathrm{CO}_{2}$ conversion is methanol. Methanol is an effective fuel due to its relatively high energy content as well as its ease of transport/storage. The benefit of producing methanol from atmospheric $\mathrm{CO}_{2}$ is two-fold; greenhouse gases 
produced from combustion would be recycled by production of a renewable fuel source. The reaction pathway for reacting $\mathrm{CO}_{2}$ into methanol is shown in Figure 8 .

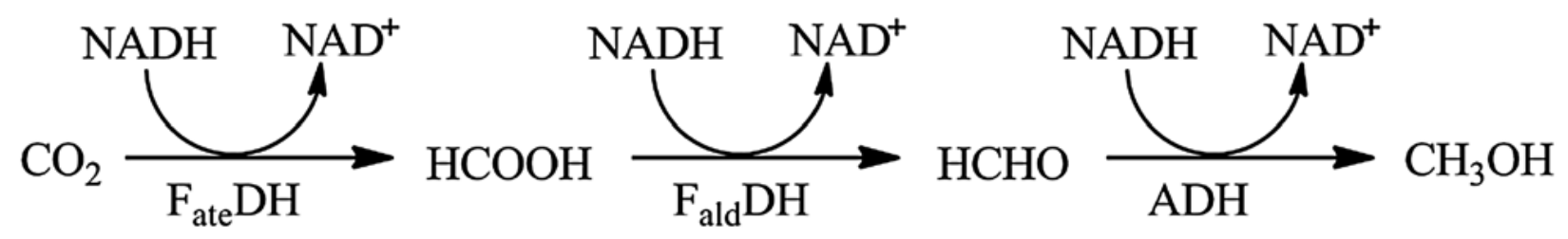

Figure 8: Reaction pathway of $\mathrm{CO}_{2}$ to methanol [9]

\section{Electro/photo-enzymatic Processes}

An emerging field of $\mathrm{CO}_{2}$ utilization, electro and photo-enzymatic processes generate free electrons to assist in the $\mathrm{CO} 2$ reduction reaction.

\section{Enzyme Immobilization}

One of the largest impediments to using enzymes in an in vitro setting, is enzyme management. Enzyme immobilization is the method of fixing enzymes to a substrate, rather than having the enzymes suspended in the working fluid. The immobilization process removes the need for a complicated filtration in the product flow stream to separate enzymes from the desired product. Immobilizing the enzymes also reduces the need to continually add new enzymes as old enzymes are lost to the product stream. One of the major hurdles of enzyme immobilization is the reduction in activity of an enzyme after immobilization.

One method being investigated for separation of enzymes in lieu of immobilization, is encapsulation. Encapsulation has several advantages over immobilization. The biggest advantage of encapsulation is there is no reduction in enzyme activity (enzymes are not being 
restricted, and thus retain full activity). The drawbacks to encapsulation include, increased complexity in manufacture (the process of encapsulating and controlling capsule size can be difficult), and an overall reduction in reaction rate due to the need for reactants and products to diffuse across the capsule membrane.

\section{Microbial Fermentation}

Utilizing microorganisms directly to convert $\mathrm{CO}_{2}$ versus isolating and producing specific enzymes is a promising avenue of research. Performing $\mathrm{CO}_{2}$ conversion to value added chemicals within selected microorganisms is desirable due to the fact that many of the more useful conversion pathways require a multitude of enzymes, along with various cofactors; these microorganisms already have systems in place to produce and regulate enzymes, as well as regenerate the necessary co-factor. Using microorganisms makes the conversion process simpler in some respects: enzymes are contained within cellular structures, therefore immobilization/encapsulation are no longer a concern, filtration of cells (with a size in the order of micrometers) is easier than filtration of enzymes (size in the order of nanometers), and production/regeneration of co-factor. There are some disadvantages to using microorganisms however: microorganisms typically require a more controlled environment to live/grow in (temperatures ranges that are acceptable for the enzymes used can kill the cell containing those enzymes), growth of cellular mass still requires some form of energy input (ultraviolet light if photosynthetic or some form of food source otherwise), genetic manipulation may be needed for 
production of specific chemicals, and some method to regulate growth is necessary (introduction of growth factors).

One of the process being investigated utilizing microorganisms is the production of isobutryaldehyde by genetically modified Synechococcus elongatus. The reaction pathway is shown in Figure 9.

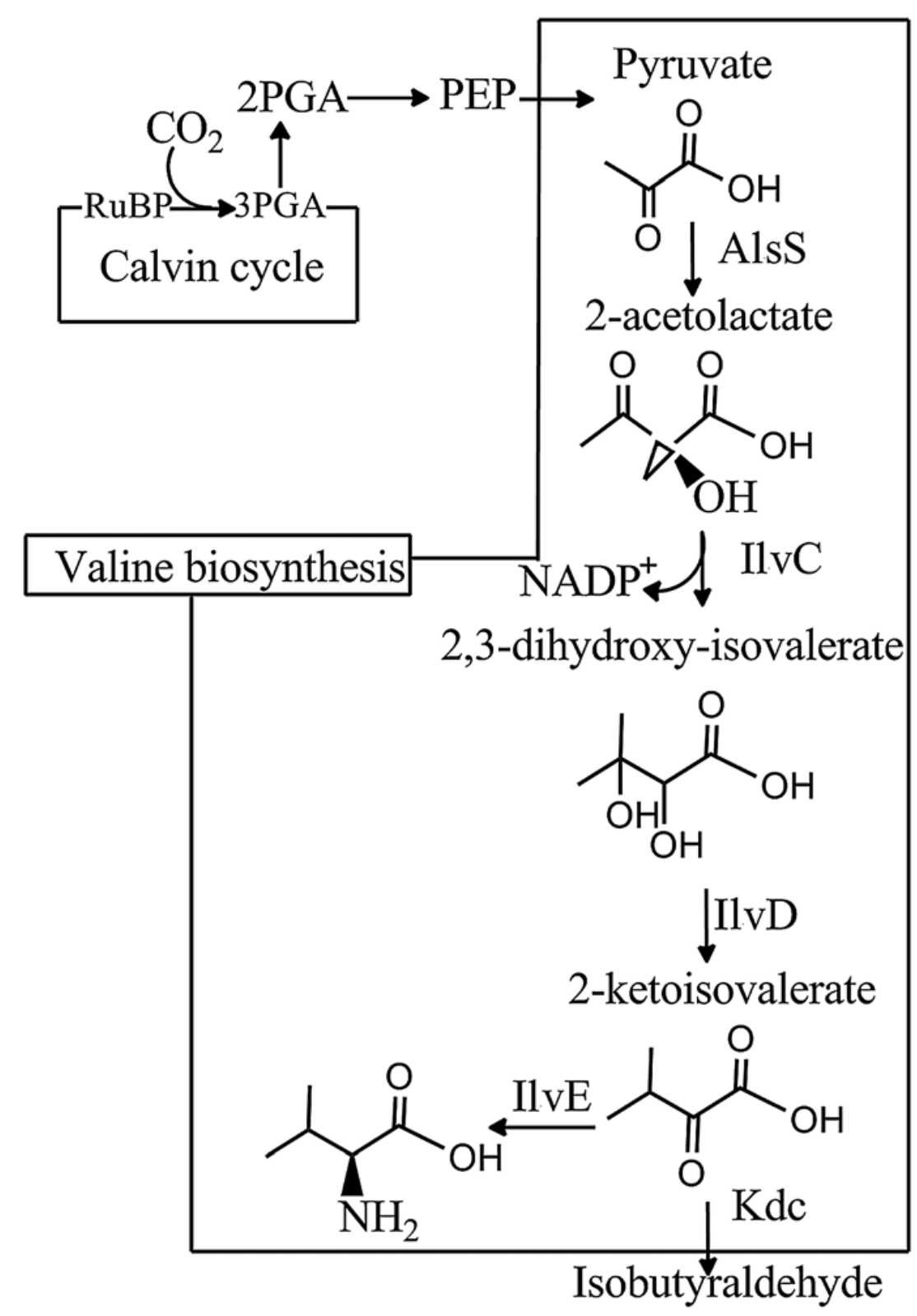

Figure 9: Synthesis of isobutyraldehyde from CO2 by Synechococcus elongatus 


\section{Discussion}

Actions need to be taken to help reduce $\mathrm{CO}_{2}$ buildup in the atmosphere. Utilizing waste products $\left(\mathrm{CO}_{2}\right.$ in this case) to produce useful, valuable chemicals is an obviously desirable scenario. The question to ask is not "Is converting $\mathrm{CO}_{2}$ to chemicals worth the effort?", but rather "Is using enzymes to convert $\mathrm{CO}_{2}$ favorable over utilizing inorganic catalysts?".

Much more research needs be done before these $\mathrm{CO}_{2}$ utilization technologies will be able to be implemented in any meaningful way. The process that has been studied to the greatest extent of the previously mentioned processes is most likely the methanol conversion process. The enzymatic conversion of $\mathrm{CO}_{2}$ to methanol was first characterized in 1999.

The current annual methanol usage in the world is approximately 100 million tons (approximately $7.76 \times 10^{9} \mathrm{~mol} /$ day), as shown in Figure 11 . Most of the methanol produced today is via syngas ( $\mathrm{CO}$ and $\mathrm{H}_{2}$ from methane) reacting over a catalyst. 


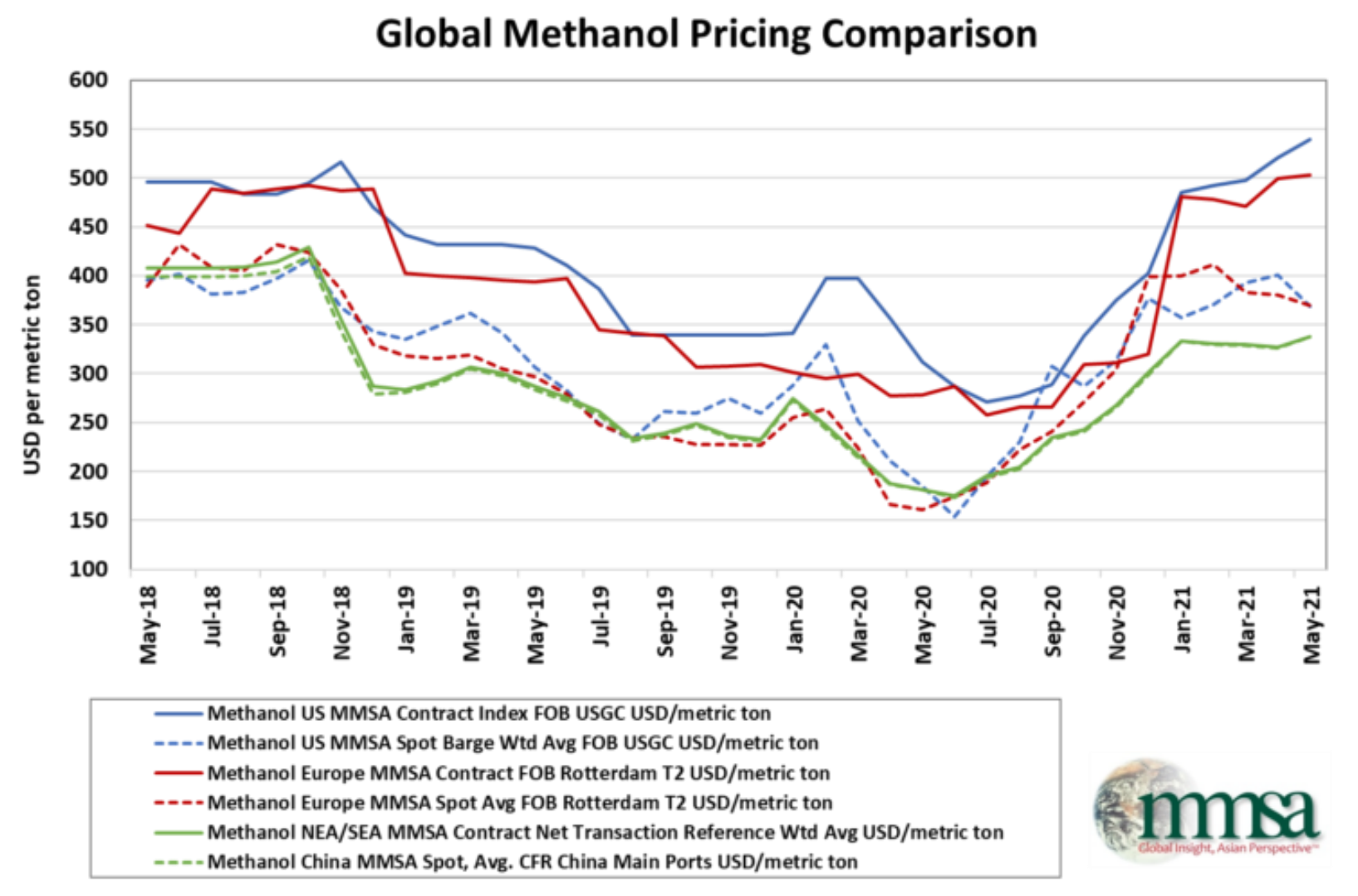

Figure 10: Methanol USD value per metric ton 44 


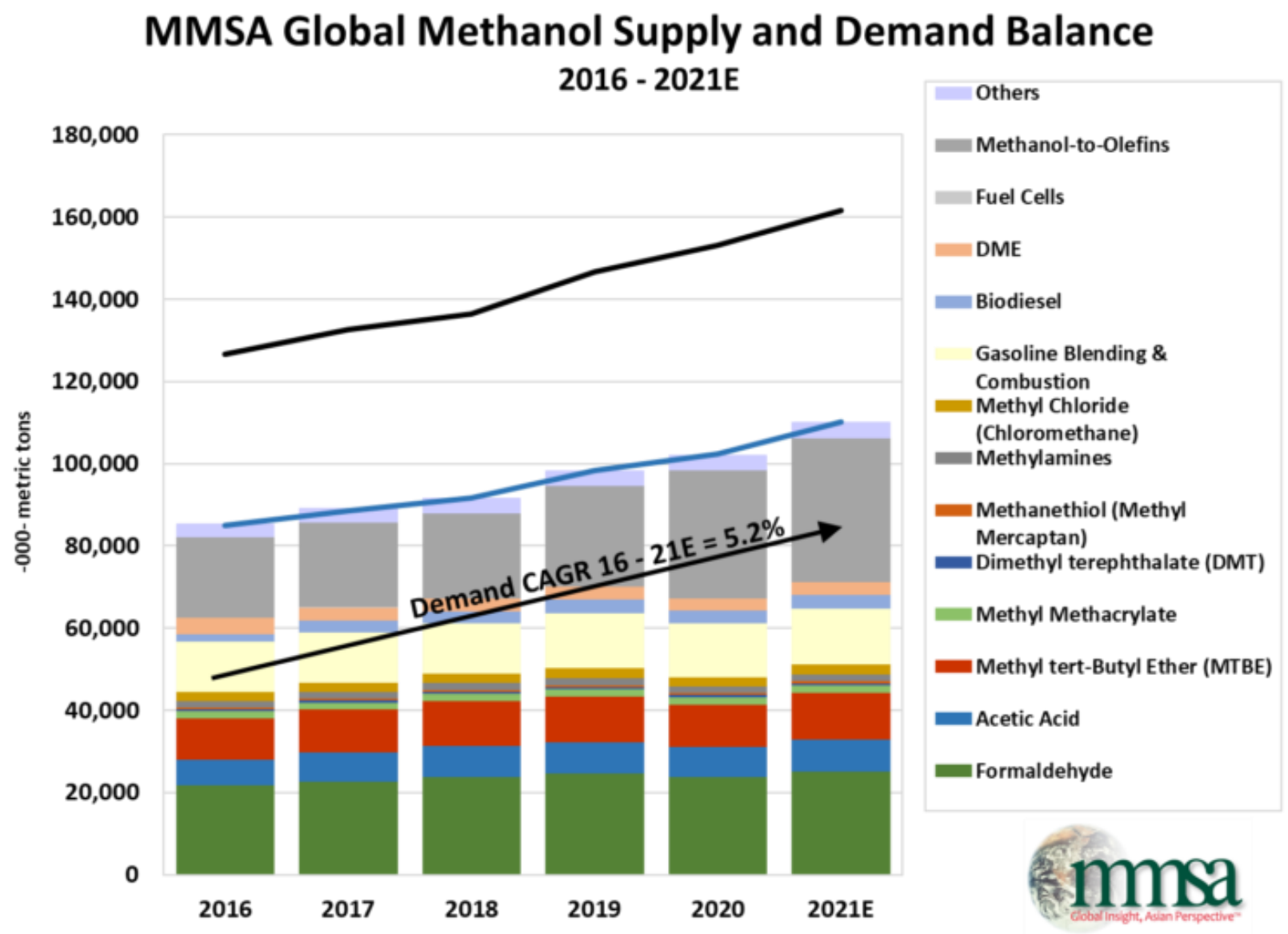

Figure 11: Global methanol demand over five-year period 44

Currently, the maximum conversion rate of $\mathrm{CO}_{2}$ to methanol from available studies is $20.96 \frac{\mu \mathrm{mol}_{\mathrm{CH} 3 \mathrm{OH}}}{\mathrm{mg} \mathrm{enzyme} \cdot \mathrm{h}} .45$ In order to meet current world demands of methanol, we would require $1.54 \times 10^{10}$ grams of enzyme (17,000 tons). These calculations do not account for the need to make up enzyme lost due to filtration or denaturing, as well as NADH requirements for this process, which would further inflate the amount enzyme (and thus overall material) required. 


\section{Future Work}

Using enzymes for $\mathrm{CO}_{2}$ conversion is still very much in the fundamental science phase. Some of the major hurdles to be overcome include regeneration of co-factor, expense of enzyme production, and sensitivity of enzymes to environment. Identifying products that would be most likely to be profitable (such as methanol) is a prospective "next step". Once a product has been identified, resources can be focused on optimizing enzymes for production of that specific chemical (likely involving genetic manipulation of a suitable existing enzyme) and reducing the cost of those enzymes.

Most of the enzymes being investigated for use in $\mathrm{CO}_{2}$ conversion are naturally occurring. The isolation and use of naturally occurring enzymes allow researchers to mimic existing biological pathways. The issue arises when attempting to scale these processes up to an industrial level. These naturally occurring enzymes typically require strict $\mathrm{pH}$ and temperature controls and can denature otherwise. A potential solution to the fragility of naturally occurring enzymes is to use protein engineering to fabricate enzymes better suited to these tasks.

Designing custom enzymes would enhance conversion rates and make enzymes that could operate at more diverse circumstances. Enzyme engineering, while showing promise, needs to be studied further (and for specific processes) to yield tangible results.

\section{Conclusion}

With growing concerns relating to rising atmospheric $\mathrm{CO}_{2}$ levels, methods to reduce the amount of $\mathrm{CO}_{2}$ released into the atmosphere are being widely investigated. Using waste $\mathrm{CO}_{2}$ to produce valuable chemicals is an ideal solution. The reality of the situation, however, is that 
more research is needed for these processes to advance from novelties to viable solutions. In addition, utilization of atmospheric $\mathrm{CO}_{2}$ will never be the entirety of the solution; other methods (such as reduction of energy usage and converting to more renewable energy sources) will need to be incorporated to impart any meaningful change. 
References

1. NASA GISS: Science Briefs: Greenhouse Gases: Refining the Role of Carbon Dioxide. www.giss.nasa.gov.

2. Chilton, Alexander (2013-10-07). "The Working Principle and Key Applications of Infrared Sensors". AZoSensors.

3. NOAA Global Monitoring Laboratory, Trends in Atmospheric Carbon Dioxide. https://www.esrl.noaa.gov/gmd/ccgg/trends/global.html

4. A.I. Bazarov, J. Prakt. Chem. 2 (1870) 283.

5. Arthur Kohl; Richard Nielson (1997). Gas Purification(5th ed.). Gulf Publishing

6. G. Fuchs, Annu. Rev. Microbiol., 2011, 65, 631-658.

7. R. Castillo, M. Oliva, S. Martı' and V. Moliner, J. Phys. Chem. B, 2008, 112, 10012-10022

8. A. M. Appel, J. E. Bercaw, A. B. Bocarsly, H. Dobbek, D. L. DuBois, M. Dupuis, J. G. Ferry, E. Fujita, R. Hille, A. R. Portis, S. W. Ragsdale, T. B. Rauchfuss, J. N. H. Reek, L. C. Seefeldt, R. K. Thauer and G. L. Waldrop, Chem. Rev., 2013, 113, 6621-6658.

9. B. El-Zahab, D. Donnelly and P. Wang, Biotechnol. Bioeng., 2008, 99, 508-514.

10. Plugge, Caroline M.; Abram, Nerilie J.; Hirst, Judy. Reversible interconversion of carbon dioxide and formate by an electroactive enzyme. Proceedings of the National Academy of Sciences of the United States of America 105(31):10654-10658

11. Machado, Iara M. P.; Yoneda, Hisanari; Atsumi, Shota. Cyanobacterial conversion of carbon dioxide to 2,3-butanediol. Proceedings of the National Academy of Sciences of the United States of America 110(4):1249-1254

12. Madras, Giridhar. Synthesis of biodiesel from edible and non-edible oils in supercritical alcohols and enzymatic synthesis in supercritical carbon dioxide. Fuel 86(17-18):2650-2659 
13. Kamiya, Noriho; Goto, Masahiro. Activation and stabilization of enzymes in ionic liquids. Organic and Biomolecular Chemistry 8(13):2887-2899

14. von Borzyskowski, Lennart Schada; Burgener, Simon; Cortina, Nina Socorro; Erb, Tobias J. A synthetic pathway for the fixation of carbon dioxide in vitro. Science 354(6314):900-904

15. Barber, James J. Photosynthetic energy conversion: natural and artificial. Chemical Society Reviews 38(1):185-196

16. Roger A RA Sheldon. Fundamentals of green chemistry: efficiency in reaction design. Chemical Society Reviews 41(4):1437-1451

17. Roger A RA Sheldon. E factors, green chemistry and catalysis: an odyssey. Chemical Communications (29):3352-3365

18. Shrestha, Pravin Malta; Liu, Fanghua; Shrestha, Minita; Shrestha, Devesh. A new model for electron flow during anaerobic digestion: direct interspecies electron transfer to Methanosaeta for the reduction of carbon dioxide to methane. Energy and Environmental Science 7(1):408-415

19. Hirst, Judy. Reversibility and efficiency in electrocatalytic energy conversion and lessons from enzymes. Proceedings of the National Academy of Sciences of the United States of America 108(34):14049-14054

20. Tao, Ling; Davis, Mark; Ghirardi, Maria; Maness, Pin-Ching. Sustained photosynthetic conversion of $\mathrm{CO} 2$ to ethylene in recombinant cyanobacterium Synechocystis 6803. Energy and Environmental Science 5(10):8998-9006

21. Yao, Lun; Gao, Qianqian; Wang, Weihua; Qi, Fengxia. Photosynthesis driven conversion of carbon dioxide to fatty alcohols and hydrocarbons in cyanobacteria. Metabolic Engineering 13(2):169-176 
22. Jiang, Yanjun; Jiang, Zhongyi; Wang, Xueyan; Wang, Xiaoli. Enzymatic conversion of carbon dioxide. Chemical Society Reviews 44(17):5981-6000

23. Dibenedetto, Angela; Quaranta, Eugenio. State of the art and perspectives in catalytic processes for $\mathrm{CO} 2$ conversion into chemicals and fuels: The distinctive contribution of chemical catalysis and biotechnology. Journal of Catalysis 343:2-45

24. Angelini, Antonella; Stufano, Paolo. Use of carbon dioxide as feedstock for chemicals and fuels: homogeneous and heterogeneous catalysis. Journal of Chemical Technology and Biotechnology 89(3):334-353

25. Donnelly, Dustin; Wang, Ping. Particle-tethered NADH for production of methanol from $\mathrm{CO}$ (2) catalyzed by coimmobilized enzymes. Biotechnology and Bioengineering 99(3):508514

26. Li, Zheng; Shi, Jiafu; Wu, Hong; Jiang, Zhongyi. Bioinspired Approach to Multienzyme Cascade System Construction for Efficient Carbon Dioxide Reduction. ACS Catalysis 4(3):962-972

27. Su, Zhiguo; Wang, Ping; Ma, Guanghui; Zhang, Songping. Tethering of Nicotinamide Adenine Dinucleotide Inside Hollow Nanofibers for High-Yield Synthesis of Methanol from Carbon Dioxide Catalyzed by Coencapsulated Multienzymes. ACS Nano 9(4):4600-4610

28. Maesen, Miranda; Dominguez-Benetton, Xochitl; Vanbroekhoven, Karolien; Pant, Deepak. Enzymatic electrosynthesis of formate through $\mathrm{CO} 2$ sequestration/reduction in a bioelectrochemical system (BES). BIORESOURCE TECHNOLOGY 165:350-354

29. Liao, James C. Photosynthetic production of 2-methyl-1-butanol from CO2 in cyanobacterium Synechococcus elongatus PCC7942 and characterization of the native acetohydroxyacid synthase. Energy and Environmental Science 5(11):9574-9583 
30. Jo, Byung Hoon; Kang, Dong Gyun; Kim, Chang Sup; Choi, Yoo Seong. Biomineralizationbased conversion of carbon dioxide to calcium carbonate using recombinant carbonic anhydrase. Chemosphere 87(10):1091-1096

31. Jiang, Zhong-yi; Xu, Song-wei; Wu, Hong. Efficient conversion of $\mathrm{CO} 2$ to formic acid by formate dehydrogenase immobilized in a novel alginate-silica hybrid gel. Catalysis Today 115(1-4):263-268

32. Buyukcakir, Onur; Je, Sang Hyun; Srinivasan, Sampath; Seo, Yongbeom. Nanoporous Polymers Incorporating Sterically Confined N-Heterocyclic Carbenes for Simultaneous CO2 Capture and Conversion at Ambient Pressure. Chemistry of Materials 27(19):6818-6826

33. Wisselink, H. Wouter; Luttik, Marijke A. H.; de Hulster, Erik; Daran, Jean-Marc. Carbon dioxide fixation by Calvin-Cycle enzymes improves ethanol yield in yeast. BIOTECHNOLOGY FOR BIOFUELS 6

34. Habulin, M; Krmelj, V. Enzyme catalyzed reactions in dense gases. Journal of Supercritical Fluids 14(1):17-29

35. GOODMAN, BJ. BIOTECHNOLOGY FOR PRODUCTION OF FUELS, CHEMICALS, AND MATERIALS FROM BIOMASS. Applied Biochemistry and Biotechnology 39:41-59

36. Tatsuke, Tsuneyuki; Tsuruno, Keigo; Hirokawa, Yasutaka; Atsumi, Shota. Engineering a synthetic pathway in cyanobacteria for isopropanol production directly from carbon dioxide and light. METABOLIC ENGINEERING 20:101-108

37. Nevin, Kelly P.; Woodard, Trevor L.; Lovley, Derek R. Converting Carbon Dioxide to Butyrate with an Engineered Strain of Clostridium ljungdahlii. American Society for Microbiology 2014 
38. Singh, Raushan K.; Nam, Dong Heon; Singh, Ranjitha; Lee, Jung-Kul. Photoelectrochemical Reduction of Carbon Dioxide to Methanol through a Highly Efficient Enzyme Cascade. Angewandte Chemie International Edition 56(14):3827-3832

39. Zong Minhua; Lou Wenyong. Recent Advances in Enzymatic Catalysis for Preparation of High Value-Added Chemicals from Carbon Dioxide. ACTA CHIMICA SINICA 77(11):10991114

40. Robinson, William E.; Oliveira, Ana R.; Zacarias, Sonia; Lee, Chong-Yong. Reversible and Selective Interconversion of Hydrogen and Carbon Dioxide into Formate by a Semiartificial Formate Hydrogenlyase Mimic. Journal of the American Chemical Society 141(44):1749817502

41. Kumar, P. Senthil; Varjani, Sunita J.; Saravanan, A. A review on photochemical, biochemical and electrochemical transformation of $\mathrm{CO} 2$ into value-added products. JOURNAL OF CO2 UTILIZATION 33:131-147

42. TSUDA, R; YONEYAMA, H. ELECTROCHEMICAL CONVERSION OF CARBONDIOXIDE TO METHANOL WITH THE ASSISTANCE OF FORMATE DEHYDROGENASE AND METHANOL DEHYDROGENASE AS BIOCATALYSTS. Journal of the American Chemical Society 116(12):5437-5443

43. Roger A. Sheldon. Biocatalysis and Biomass Conversion in Alternative Reaction Media. Chemistry - A European Journal 22(37):12983-12998

44. "Methanol Price: Methanol Institute: Www.methanol.org.” METHANOL INSTITUTE, 8 June 2021, www.methanol.org/methanol-price-supply-demand/. 
45. X. Ji, Z. Su, P. Wang, G. Ma, S. Zhang, Tethering of nicotinamide adeninedinucleotide inside hollow nanofibers for high-yield synthesis of methanolfrom carbon dioxide catalyzed by coencapsulated multienzymes, ACS Nano 9(2015) 4600-4610. 